\section{The Western Micronesian Sprachbund}

Anthony P. Grant

\subsection{Introduction}

Thomason (2000) has written about the difficulties involved in proving that constellations of shared features, which are found among a number of languages spoken in the same region, means that the languages in question constitute a linguistic area. Such heuristic problems will be discussed here in regard to the potential sprachbund status of Western Micronesia in the northwest Pacific, an area which has been characterized by extensive and intensive networks of language contact.

The languages involved here are Trukic or Chuukic, especially western Trukic varieties, ${ }^{1}$ Yapese of the island of Yap, now part of the Federated States of Micronesia, Palauan of Palau (now the Republic of Belau), and peripherally - Chamorro of the Marianas. Mapian, a Trukic variety, was spoken a little north of Irian Jaya (see Map 30.1 for locations in Micronesia). Like Sonsorolese-Tobian and Pulo Annian, it was spoken considerably to the west even of Palauan and Yapese, so that the spread of Trukic languages is the greatest of that of all the languages discussed in this chapter. The westernmost and easternmost languages of Western Micronesia that are discussed here, Chuukese and Sonsorolese, are both Trukic.

Among the Trukic languages, Sonsorolese-Tobian, the westernmost one which is spoken several hundred kilometres away from the epicentre of Trukic languages, is especially archaic at the phonological level, such that Sonsorolese phonological forms are closer to the phonological shapes of cognate stems in other Nuclear Micronesian languages than other Trukic

would like to thank the members of the NWCL, as well as Bob Blust, Francesco Goglia, the late Thomas Klein, Laurie Reic Malcolm Ross and Sakiyama Osamu for various forms of help w wht this chapter

Sonsorolese-Tobian and Pulo Annian, Ulithian, Woleaian and varieties of Saipan Carolinian, a migrant language from the central Trukic belt; Puluwatese, Mortlockese and Lagoon Trukese or Chuukese are also Trukic languages, while the extinct language of Mapia is the westernmost Trukic language of a

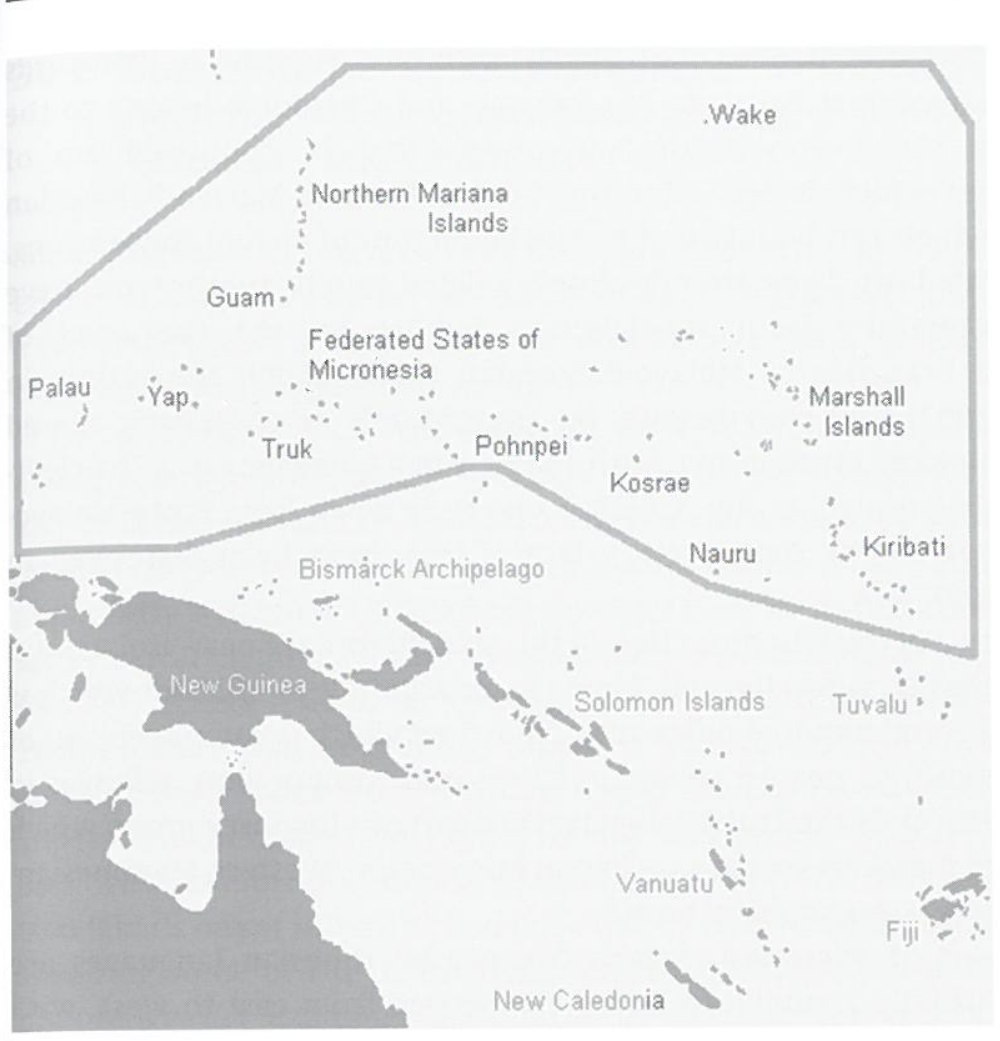

Map 30.1 Micronesia area of the Western Pacific ${ }^{2}$

forms are. ${ }^{3}$ Like Woleaian (though more comprehensively) it preserves on stems the word-final voiceless vowels which manifest themselves only in inflected forms in other Trukic languages. Either SonsoroleseTobian is phonologically conservative because it has moved little from the first point of settlement of speakers of Trukic languages, or because, surrounded by speakers of Palauan (and Yapese), it has remained isolated from waves of phonological change which have spread throughout the rest of the Trukic continuum.

All of these languages belong to the Malayo-Polynesian branch of Austronesian, so they are ultimately related to one another, though at considerable time depths. Most of them are Oceanic: Trukic participates in Nuclear Micronesian, Yapese is possibly part of the Admiralties group of languages, originally from northeastern Papua New Guinea, and which constitute a primordial division of Oceanic; indeed Ross (1996) suggests that these languages were probably the first languages to break away from the rest of Oceanic 4 Proto-Micronesian has been

Map by courtesy of Holger Behr, licensed under Public Domain via Wikimedia Commons Evidence for a Tobian-based pidgin from the 1830s is presented in Holden (1836) and discussed in Grant (2014). In more recent work, for instance in Lynch, Ross and Crowley (2002), Yapese is represented as the first division of Oceanic against all the other Oceanic languages, which are then divided into Admiralties languages versus all the others 
reconstructed by Bender et al. (2003), with due attention to loanwords and other contact features. But Palauan and Chamorro belong to the Western Malayo-Polynesian 'anti-group': that is, the residuum of languages which is left after the Central-Eastern Malayo-Polynesian group, which can be justified by the adduction of shared innovations, is separated off. They are not closely related to one another and have not successfully been subclassified further beyond the level of separate branches of Malayo-Polynesian (Blust 2000); the claims in Zobel (2002) that they belong, on the grounds of possessing shared morphological innovations, with many other languages in a 'NuclearMalayo-Polynesian' group, which is one rung down from Proto-MalayoPolynesian in the Austronesian family tree, have been disproved in Reid (2002).

Thus two of the four groupings in this sprachbund are near-'isolates' (in relative terms, naturally) and Yapese is an Admiralties offshoot which is spoken several hundred miles away from (and which is completely out of contact with) its nearest genetic relatives and without close relatives in Micronesia. Only the Trukic languages are part of a linguistic group which has other members that are spoken in Micronesia. 'Western Micronesian' is therefore a geographical term. ${ }^{5}$

The part of Micronesia where Nuclear Micronesian languages are used is usually assumed to have been settled from east to west, with Kosrae as an early landfall (see Jackson 1983), though the centre of greatest linguistic diversity among Nuclear Micronesian languages is in the southeast, and according to Ross (1996), lexical evidence from the reconstruction of Nuclear Micronesian, naming geological and similar items, suggests that the proto-language was spoken on a high island such as Kosrae rather than an atoll such as Chuuk. Ross (1996) and Blust (2000) each suggest that the period of continued settlement of Nuclear Micronesia and the Marianas respectively took place between 3,000 and 3,500 years before the present, and Blust (personal communication to Anthony Grant, April 2002) has suggested that Palau may have been settled some millennia ago from the Talaud Islands off Sulawesi, where Sangiric languages (part of the Greater Central Philippine group of Austronesian languages) are now spoken, but that this does not imply that Palauan is Sangiric. We are less sure when Yap was first settled, but the overall picture is that most of the linguistic components of this potential sprachbund were in place a few millennia ago.

5 For the record, the languages of Eastern Micronesia - the other Trukic languages, the Ponapean languages Kosraean, Marshallese, Kiribatese - are mostly part of the deeply ramified Nuclear Micronesian subgroup of Oceanic, although Nukuoro and Kapingamarangi, spoken to the south of the eastern Trukic languages, are Polynesian outliers, and it appears that Nauruan is coordinately related to the Nuclear Micronesian languages os their closest genentic relative
30.2 Some Intense 'Contact Languages' in Western Micronesia: Contact-induced Change in Nguluwan, Carolinian and Chamorro

Some languages in this area have been especially strongly shaped by the effects of language contact or contact-induced linguistic change, and as a result they seem at first hand to be ideal places to look for the bundling together of areal-linguistic features.

There is, first of all, the question of Nguluwan (Sakiyama 1982), a language which is spoken by a few score people living on Ngulu(w), an island included in Yap. This is a variety of Yapese used by a population which is (or was recently) bilingual in Ulithian (some older Nguluwanese apparently still know Ulithian but younger ones do not). It contains the same lexical elements from Palauan which Yapese contains (in addition to a few others unique to Nguluwan), but in addition to the western Trukic loans which are found in Yapese, it has an extra layer of both basic and non-basic loans from Ulithian which are not found elsewhere in Yapese. Furthermore, both typologically and phonologically it resembles Ulithian more and Yapese less; for instance, it has developed velarized labials out of inherited and pre-existing non-velarized forms, while shedding some of the distinctions which are characteristic of Yapese phonology. For example, the feature of glottalization has been shed from Nguluwan phonology and Yapese glottalized consonants are unglottalized consonants in Nguluwan, although eleven pairs of Yapese consonants, including some continuants, distinguish glottalized and unglottalized forms. Yapese is the only language among those of Western Micronesia which has any glottalized consonants apart from the simple glottal stop, which is widely distributed within Micronesia. This loss in Nguluwan is probably the result of language contact involving Ulithian, as Ulithian lacks these sounds.

Another language which deserves attention here is Carolinian (sometimes called 'Saipan Carolinian'), which is spoken in three dialects on Saipan in the Northern Marianas, dialects which have their origins on Satawal, Lamotrek and the Mortlocks respectively, all of them central or (in the case of Mortlockese) eastern Trukic lects which have been transported northwest to Saipan, where they have all been influenced by the same languages. In terms of historical and numerical precedence the major sources of loans into Carolinian are Chamorro, Japanese and English, with a handful of words also taken from German. It appears from my study of Fritz (1911) and Jackson and Marck (1991) that the bulk of Chamorro copies into Carolinian are themselves copies from Spanish, constituting a subset of the massive tranche of Spanish items which have been copied into Chamorro. It is furthermore clear that Chamorro is the source of most if not all Spanish elements in Carolinian, and that additionally most of these 
loans are 'acculturational' items inasmuch as they are phonologically Carolinianized versions of the names of introduced items from the various languages of the people who introduced these items to the Carolinians.

The degree of copying of elements from other languages into Chamorro itself deserves some analysis. The copying profile of Chamorro is interesting, since the Marianas had a different colonization pattern from the Carolines (which include the islands on which the other languages which we are concerned with here are spoken). In fact, Guam had a different pattern of settlement from that of the Northern Marianas, and this is instantiated linguistically. The important factors here are historical: contact with Spaniards since the 1520 s and settlement by the Spanish of Guam from the 1660s onwards, the decimation of the Chamorros and the relocation of all Chamorros from Saipan and other northern islands onto Guam (apart from a maroon group which remained on Rota), the landing of the first boatload of Carolinians on Saipan in 1815 the resettling of some Chamorros on Saipan in 1817, and the occupation of Guam by the Americans in 1898 but the cession of the northern Marianas by Spain to Germany from 1899 to 1915, with their post-WWI cession to Japan, which based its regional headquarters on Saipan (Japan also occupied Guam during WWII), and the transfer of all these islands to the US in 1945. Salas Palomo and Stolz (2008) discuss the impact of Spanish on Chamorro and on attempts to 'reaustronesianize' the language. The book by Rodríguez-Ponga Salamanca (1995) is the largest study of the impact of Spanish on Chamorro, but Blust (2000) indicates that Tagalog or other Philippine languages, and also a Malayo-Polynesian language which has yet to be identified, have also shaped the language. This was noticed by Costenoble (1940). A few other forms of varied origins (Palauan, Chuukese, Pidgin English) are listed in Blust (2000).

Saipan Chamorro contains lexical elements deriving from Japanese, and these are not found in Guamanian or Rotanese forms of Chamorro, which have absorbed more forms from English (as has Saipan Chamorro). As we saw above, Saipan Chamorro has given many copies to Carolinian, many of these being of Spanish origin. Neither variety has copied much from German (there are a very few German loans in Carolinian and none in Chamorro). The reason for this is that the Chamorros had a greater and longer exposure to European cultural elements than any other Micronesians (including the Carolinians), and they had already adopted the acculturational lexicon which they felt they needed to have from Spanish. No other Micronesian language has copied more than a handful of (acculturational) loans from Chamorro. I do not know of any loans from Carolinian that occur in Saipan Chamorro, and given the disparity of the low status of the Carolinians and their language as against that of the Chamorros on Saipan in earlier days, we might be surprised to find any such loans.

\subsection{Areal Features in Western Micronesia: Lexical} and Structural Elements

These languages of Western Micronesia show partial convergence over time through the sharing and spread of many structural features, especially some highly marked phonotactic and morphosyntactic properties, which are absent in many of the languages spoken nearby. Additionally, they share further structural features (and these are mostly typological rather than morphological, transfers of pattern rather than transfers of fabric: Grant 2002a, 2003), which are presumably inherited from ProtoMalayo-Polynesian.

There is also a plentiful body of shared lexicon of various kinds, which can be stratified historically: there are many items of shared inherited Malayo-Polynesian lexicon, additional items originating in one language which passed to others in the group (with words flowing especially from Palauan and Trukic to Yapese: Ross 1996), and later shared cultural loans from Philippine languages, German, Spanish, Japanese and (in most cases) two layers of loans from English, one from the Pidgin English which was used by nineteenth century American whalers and traders who visited Micronesia, and the other as a result of the influence of post-1945 American administrators and educators. American missionaries who had previously established Protestant missions further east in Micronesia are also responsible for the loans from Mortlockese and Pohnpeian which one finds in some eastern Trukic lects.

Generally, the major direction for copying lexicon in Micronesia is from west to east. Loans, mostly labels for acculturational items, diffused from beyond Micronesia and from imperial administrative centres (e.g. Koror on Palau and Donguch/Colonia on Yap) to more easterly or less politically dominant locations. Most of these come from European languages but some are items from other 'Western Micronesian' languages - for instance the name of the mineral 'lime', which is often incorporated in betel chews (Palauan chaus /Paus/, from Proto-Malayo-Polynesian (PMP) "qapuR; it also means 'white' in Yapese), diffused from Palau (which has the phonological reflex for this word which one would expect from the processes of Palauan historical phonology: Grant 2002a) into Yapese and Nuclear Micronesian languages as far east as Kosrae (Ross 1996).

A few other words are widely dispersed. 'Pig' is labelled as vaviy in Yapese, itself a copy from Tagalog baboy by way of Chamorro babui and then via Palauan babii. 'Rice' in Woleaian is peraas, probably from Palauan beras, which has taken it from Malay beras (Chamorro has the expected reflex of this word, namely pugas, cf. Bisayan bugas). The word for 'paper' in Chamorro is Spanish-derived papet, complete with the usual Chamorro reflex of syllable-final /-1/. But in Palauan it is babier, from German Papier which has passed into Yapese as babyoor (it has clearly come into Yapese 
from Palauan since Yapese distinguishes between $/ \mathrm{p} /$ and $/ \mathrm{b} /$, though Palauan did not do so at this time), and thence into Woleaian as babigo This is a form which indicates that some diffusion of European cultura items and their labels occurred from west to east into the era of German occupation. Palauan and Yapese speech communities had apparently not quite lost all contact and ability to influence one another by the time the Europeans began to exert substantive influence in the area at the start of the twentieth century.

A table of major sources of loans in the various languages is presented in the Appendix as Table 30A.1. It needs to be recognized that by no means al the lexical elements in any of these languages have been fully sourced. For instance, Blust (2000) argues for the existence of an extensive stratum of phonologically distinctive but as yet unsourced etyma in the Chamorro vocabulary, in addition to an under-explored stratum of words which have been taken from one or more Philippine languages, possibly with Spanish 'assistance' inasmuch as they relocated many Filipinos to Guam. ${ }^{6}$ This stratum postdates the split of these languages from Proto-Malayo-Polynesian but is apparently pre-Spanish (and pre-Philippine contact?) in its dating.

Some common structural features, which are often cross-linguistically unusual but which are found in this area, are given in Table 30A.2 (phonological features) and Table 30A.3 (morphosyntactic features) in the Appendix. In this examination I have prioritized phonological features, which are easier to identify, though there are also many cross-linguistic parallels in morphosyntax. Not all these shared features are diffused. Some have simply been inherited from the proto-languages of the various languages under discussion, and thus may be shared with Admiralties languages in the case of Yapese or with other Nuclear Micronesian languages in the case of Trukic. Others may go back to Proto-Malayo-Polynesian.

Similarly the value of these features for proving Western Micronesia as a sprachbund varies intrinsically from feature to feature. Some features are simply stronger evidence, because the phenomenon which they instantiate is less frequent universally than others are. For instance, not all of the world's languages have both prefixes and suffixes, but all four groups surveyed here use both prefixes and suffixes, especially in the verb complex. Is this then a strong feature with which to prove the existence of this sprachbund? There again, what really is the probative power for the construction of a sprachbund (if it has any)? Is it the fact that all the languages in Western Micronesia (apart from Chamorro, which uses only Spanish loans) denote 'twelve' by expressions which translate as 'ten and two'? Or the fact that the pronominal systems in all four groups distinguish between inclusive and exclusive first person plural, just as Proto-Malayo-Polynesian did? Or the fact that, like most Austronesian languages, they are all prepositional rather than postpositional languages?

Even when we have evidence of shared features which are crosslinguistically highly marked, they do not always present the uniform picture of origin, distribution and development which we may expect, and their various origins may be very different from language to language. For example, Palauan, Yapese and Trukic all permit word-initial geminate clusters. And yet these are infrequent in Palauan and are probably of recent origin there, though other initial CC-sequences involving different consonants are fairly common. Yapese has such clusters, but they are found only with sonorants and are also infrequent, while the only other CC-initial clusters in Yapese are infrequent dissimilated clusters such as that found in bpiin 'woman' (Jensen et al. 1977). On the other hand, while geminate initial consonant clusters are both basic and very frequent in Trukic languages, other CC-clusters, in which the first and second consonants are different, are not attested there. Meanwhile, Chamorro, which does not permit word-initial geminate consonant clusters (though these are common enough word-medially), still has a great proportion of CCinitial stems, but these were unknown before the impact of Spanish on Chamorro, and Spanish is the source of the vast majority of these forms.

\subsection{On the Difficulties of Showing that Western Micronesia is a Sprachbund}

In substantiating Western Micronesia as a potential sprachbund we may discuss probative issues which are raised by the fact that two of the four participatory stocks, namely Chamorro and Palauan, lack close relatives, while the genetic connection of Yapese to the Admiralties languages has been obscured on both sides by millennia of separate internal development (and in the case of Yapese, also hundreds of years of intimate contact with speakers of other Austronesian languages). We should try to separate diffused from inherited features among a group of ultimately related languages. We may further discuss the paradox that many typological and especially phonological features connecting these languages appear to run in the opposite direction from those features mediating lexical influence.

An important first stage when looking for possible sources of linguistic change is to start with lexical transfers and to list the sources of the lexical loan elements in the various languages: Trukic, Patauan, apparently Malay, Philippine languages, German, Spanish, Japanese, two layers of English loans (the first layer of which was introduced by nineteenth century American whalers and thus predating German and Japanese elements in these languages) as well as Chamorro. Some languages have acquired elements from further languages (there is a small Western 
Malayo-Polynesian tranche of loans in Chamorro, Palauan and Yapese, and loans from other Trukic languages and Pohnpeian in Trukic languages) and there appears to have been some 'dialect mixture' among Trukic languages and beyond (there have been a few mission-actuated, postEuropean contact, acculturational borrowings from Pohnpeian postMortlockese into Lagoon Trukese and Puluwatese, for instance, as the material in Goodenough and Sugita 1990 shows).

The effects of borrowing on each language should be noted, as it is not enough simply to count loans: with just under 600 recognized loans in a list of c. 3,000 discrete lexical stems, Yapese has proportionately slightly fewt borrowings than Lagoon Trukese (Goodenough and Sugita 1990 indicate that Lagoon Trukese has about 760 recognized loans as against c. 3,000 nonloan stems). But the impact of loan elements (especially from Austronesian languages) on Yapese is important out of all comparison to the impact of borrowing on Lagoon Trukese or on any other Trukic language. The everyday non-acculturational vocabulary of Chuukese (or for that matter Puluwatese) is unaffected by loans from Japanese or English, but the basic vocabulary of Yapese is full of loans (especially nouns) from Palauan and even more so from Ulithian. This has happened to such an extent that the ultimate affinities of Yapese were long in doubt; even Blust (1980: 152) assumed that Yapese was derived from a creole, of which a key component was Palauan while another was an unidentified Oceanic language.

There is also the issue of lexical and morphological elements which are independent innovations and which have not arisen as the result of contact-induced language change. Some 110 items on the Chamorro translation of the Blust list, ${ }^{7}$ about 120 on the Palauan Blust list, and maybe two-thirds of the relevant elements on the Yapese Blust list, all fall into this category.

Indeed, Yapese shows a very great degree of independent innovation, as well as having received an inordinate number of lexical borrowings from neighbouring languages (and on the Blust list these almost exceed the number of elements retained from Proto-Malayo-Polynesian). One such innovation is the development of a separate set of glottalized consonants (both stops and continuants), which are found nowhere else in Micronesia (so they cannot have been introduced through the transfer of numerous loans from relevant languages) but which are quite frequent in Yapese. In Yapese they represent the end-result of a process of reduction of what were originally CVC-sequences. Another innovation, which appears to be fairly recent if we are to judge from the scant philological evidence, is the development of original Yapese voiced stops into voiced fricatives in most instances. This change is not found in other Western Micronesian languages.
There are historical reasons for bracketing these languages of Western Micronesia together as a linguistic area and for positing a history of cultural exchange between several of the islands and atolls, given the role of the maritime Yap empire in pre-modern times, the role of Ulithi as the major atoll group within this empire, and the Yap Empire's dependence upon pieces of stone money which could only be obtained from Palau. Yapese did not apparently influence Palauan, lexically or otherwise and at a very basic lexical level, but the reverse flow of influence did take place Meanwhile Yapese borrowed much basic vocabulary from Ulithian and donated a certain amount of cultural vocabulary to it and to Woleaian. We can additionally trace the patterns and directionality of influences, or at least explore some of the history of such influences, by doing philological work on some of these languages; this is especially feasible with Chamorro but it can also be done with Palauan, Yapese and Woleaian to a lesser extent, and there is a certain amount of older data on the dialects of Carolinian. In this light, a study of the Chamorro, Woleaian and Yapese vocabularies in Chamisso (1864), collected in 1817, shows that Yapese had already absorbed its Ulithian and Palauan elements but that Chamorro's inherited sets of numerals were still obtainable as artefacts from some Chamorro-speakers (the others having switched to using Spanish numerals only).

\subsection{Common Phonological Developments which Cut across 'Genetic' Boundaries in Western Micronesia}

Several important changes from the phonological system reconstructed for Proto-Malayo-Polynesian show parallel developments in more than one of the four branches in Western Micronesia:,

PMP *P > /f/ (Chamorro, and possibly earlier in Palauan where it is now $/ \mathrm{w} /$ ),

$>/ \mathrm{w} /$ (Palauan, Trukic when it occurs before back vowels, Yapese)

PMP*s $>/$ t/ (Palauan, Woleaian)

PMP*b $\quad>/ \mathrm{P} /$ (Chamorro; Trukic and Oceanic languages generally where this merger occurs)

PMP $*_{n} \quad>/ I /$ (Palauan; Ulithian, also in the Tanapag form of Carolinian, though it does not occur in all Trukic languages ${ }^{9}$ )

PMP *t $>/ d /$ (Palauan), /Ø/ (Trukic languages).

PMP*d $>/ r /$ (Palauan, Trukic)

There are other important phonological trends which are distributed across genetic boundaries in Western Micronesia. A fhotic/sibilan

"This is alluded to in Walsh and Harui-Walsh 1979; see also the short list of loans from Yapese into Woleaian which is 9 given in Sohn 1975

changes original $/ / /$ to $/ /$. 
interplay, manifested in several ways, is found in some Western Micronesian languages: PMP ${ }^{*} \mathrm{R}>/ \mathrm{s} /$ in Palauan (and in earlier Patern loans into Yapese it was represented as $|c|$, presumably close to the sound which it had in Palauan at the time). The same sound is represented by trilled and assibilated rhotics in some Trukic languages (it occurs thus in Satawalese and Puluwatese) and by a retroflex sibilant or other kinds in sibilant in some others, such as Woleaian (and by palatal stops or affricates in yet others, such as Lagoon Trukese and Ulithian).

There is also a tendency for major words (especially contentives) in surface forms in Western Micronesian languages (and some beyond) to be C-initial and C-final, e.g. in Palauan, Yapese and to a large extent also many Trukic languages (certainly Puluwatese). Chamorro and Palauan prefix epenthetic consonants to vowel-initial words (/gw, $g /$ in Chamorro and $/ \mathrm{y} /$ in Palauan), while Yapese uses word-initial (and word-final) glottal stops to reinforce the use of the C-initial and C-final template, and Trukic languages prefix $|\mathrm{w}|$ to word-initial back vowels and $|\mathrm{y}|$ to front vowels. These principles are relaxed with regard to post- 1885 loans in some of the languages, which permit loans that can be vowelinitial and vowel-final, although the rule had already been relaxed by the time Spanish loans flooded into Chamorro. Initial CC-clusters are only found in Chamorro (in loans only), in Palauan (where they are secondary and are usually broken up at the phonetic level by a svarabhakti schwa) and in a small number of stems in Yapese, such as bpiin 'woman', where it looks, on the basis of comparative evidence (cf. Proto-Polynesian "fafine and modern Hawai'ian wahine), as though an intermediate vowel was recently deleted.

A third phonological tendency is for there to be essentially one stop series in these languages in terms of the lack of contrastive voicing, although allophonic conditioning through gemination (not a process present in Proto-Malayo-Polynesian phonology) and other changes can have their effect in phonetic realizations. Trukic languages have one stop series (as is the case with many other Oceanic languages), while Palauan has $/ \mathrm{b} /$ but no $/ \mathrm{p} /$ except in recent loans from Japanese and English, / $\mathrm{k} / \mathrm{but}$ no $/ \mathrm{dg} /$, and a voiced interdental fricative $/ \partial /$ but no voiceless one, plus $|s|$ but no $|z|$ until that was introduced in recent Japanese loans. Yapese has two sets of voiceless consonants (glottalized and unglottalized) as well as a voiced set, which is usually realized as voiced fricatives. Chamorro turned the voiced stops into voiceless ones, turned $/ \mathrm{p} /$ into $/ \mathrm{f} /$ and earlier $/ \mathrm{k} /$ into $/ \mathrm{h} /$ (though $/ \mathrm{kk} /$, if it is inherited from forms occurring in Proto-Malayo-Polynesian though this is a language lacking geminate consonants - remains intact in Chamorro). But Chamorro kept $/ t /$ as $/ t /$, and eventually turned PMP * $R$ into $\mathrm{lg} /$, as did many Western Austronesian languages, while PMP *Z became /c/. Blust (2000) points out that $/ \mathrm{b} \mathrm{d} \mathrm{k} /$ are indicative of loanwords in Chamorro, as is $\mid \mathrm{r} /$. Not all these loans are Spanish or Philippine in origin, though many of them are; where the remainder come from has as yet not been ascertained.

Of course there are other Proto-Malayo-Polynesian sounds which have produced different reflexes in each of the four branches. PMP * $\mathrm{R}$ is the most notable of these: it goes to zero in Trukic, $/ \mathrm{r} /$ in Yapese, $/ \mathrm{s} /$ (formerly $/(/)$ in Palauan and $/ g /$ in Chamorro. It is also too easily forgotten that there are many more features which set these languages apart than which unite them. For instance, Chamorro has a 'Philippine-type' goal-focus system, part of which is also found in Palauan, and which can be reconstructed back to Proto-Austronesian. But this system is not found in either Yapese or Trukic. The structures of tense-mood-aspect systems are more complex in both Yapese and Trukic than in Chamorro, with Palauan standing between these poles in having a system of 'medium complexity'.

When looking for possible sprachbund features, we need to separate out universals and near-universals from features which were inherited from the proto-language, and distinguish these from further features which have been transmitted by diffusion and from yet other features which languages have evolved individually. The features which enable us to build a plausible sprachbund are 'shared diffusions' in typology, and these consist of innovations which arose in one language and which have spread by contact to others. As such they are analogous to the shared innovations whose presence enables us to subgroup clusters of related languages in genetic classifications.

\subsection{How Did the Sprachbund Come About? Earlier Contact Patterns}

The question is how these features diffused from one language to another. Instead of looking at the whole region as a massive sprachbund, we can usefully decompose the territory into smaller portions, in terms of the patterns of diffusion. The domain of the Yap Empire or at least a tributary system centred on Yap, with the interaction of speakers of western Trukic, Palauan and Yapese itself, is one such sub-area. Guam and the Marianas are home to Chamorro, which has had a much longe period of closer interaction with speakers of European languages than the other languages have had, which shows very different patterns of massive borrowing from those found elsewhere in Micronesia, and which is peripheral to many of the shared areal features. ${ }^{10} \mathrm{~A}$ third factor enhancing the possibility of the geographical spread of changes is the superb knowledge of traditional techniques of navigation among 
speakers of Trukic languages, which are still preserved to this day on the atoll of Satawal. This enabled them to make long voyages to the distant islands and helped linguistic innovations to diffuse very far though some of these innovations never reached the far western Truki languages.

We may mention here the presence of some possible Micronesian (Trukic and maybe Palauan) elements in Chamorro. Can we detect language shift from these languages to the more powerful Chamorro? Thi stratum of forms includes apparently Trukic (or at least Nuclear Micronesian) forms such as pwengi 'last night', bwente 'perhaps' (cf. Carolinian bwete 'although'), yalibaw 'to thrash', gwatu 'there', sirek 'to copulate'; and a couple of forms which may (according to Reid 2002) be from Palauan: palau'an 'woman', possibly once 'Palauan woman slave', and un (an oblique form for 'you plural'). The Micronesian-derived forms are common to all forms of Chamorro, including that of Guam; they are not recent loans into Saipan Chamorro from Carolinian. The possibility of the existence of a sizable Micronesian or Palauan component in Chamorro has never been clearly detected, let alone been explored in extenso, but the chance that some speakers of Guam Chamorro once had ancestors speaking Micronesian languages cannot quite be excluded. But even though Trukic substrate languages (or stray speakers of Trukic languages who were washed off course during their voyages) may have influenced Chamorro, there is no evidence that this happened to Palauan. There are some speakers of Sonsorolese-type dialects who live in Chechang Village on Palau, but they are relatively recent migrants there. The reduction of the consonant inventory of Palauan appears to have been an independently motivated phenomenon.

\subsection{Conclusions}

The arguments for the existence of a Western Micronesian sprachbund are largely phonological and lexical in nature, and it is anomalous that the language which has most closely approximated the Trukic phonological system (especially in regard to the abolition of voicing as a distinctive feature) is Palauan, which has had the least contact with, and which is the one least influenced by, Trukic languages. The morphosyntactic characteristics which mark these languages as being similar are (1) mostly typological rather than overtly morphological in nature, instances of similar patterns rather than similar fabric, ${ }^{11}$ and (2) (probably) inherited rather than diffused.
I use parentheses for the word 'probably' because we cannot always tell whether these features were diffused or inherited. There are two reasons for this uncertainty: (1) because our records of these languages are mostly too recent for us to be able to discern this, and (2) because Chamorro, Palauan and Yapese are each of them languages with no close relatives. ${ }^{12}$ Many of the features which bind these languages together may have been inherited from earlier stages of MalayoPolynesian. Syntactic influence of one language upon another is clearest where it is most discordant, thus it has clearly taken place in Nguluwan under Ulithian influence (for example in the way of handling alienable possession in nouns) and in Chamorro under Spanish influence (where it is manifested in the borrowing of many conjunctions and modal and temporal adverbs, which are sometimes semantically reinterpreted). But the unusual form of possession in Chamorro exemplified by ga'-ña haguini [ANIMAL.CLASSIFIER-3SG sandcrab] 'his sandcrab' (Topping and Ogo 1980: 289) is strongly reminiscent of the Trukic possessive constructions which are found in Nguluwan because of its Ulithian element.

We are dealing with several different kinds and degrees of influence and change here, a situation which has to be examined on a language-by-language basis. The impact of Spanish on Chamorro is a case of unidirectional language contact on a scale unprecedented elsewhere in Micronesia, although these do not impinge very heavily on the vocabulary of the Chamorro translation of the Blust list, where they constitute only 3-4 per cent (they are more prominent among the elements of the Swadesh list). A further 2 per cent of the items on the Blust Palauan list are acquired from other languages (Spanish words for 'salt' and 'root' and Japanese for 'dust' and one form for 'egg'), and even these are anomalous as instances of relexification (rather than extension) in the Palauan vocabulary; Palauan has mostly absorbed new labels for new items, and apart from possibly borrowing the Oceanic applicative *-akini as -akl on some verb stems which cannot be analysed within Palauan morphology (Zobel 2002), there is no concrete evidence for transfer of fabric into Palauan from Oceanic languages, although the Palauan phonological system does read a bit like a parody of a Nuclear Micronesian phonologica segment roster.

On the other hand, the impact of other languages upon Yapese is profound. In the lexicon alone, there are about 30 borrowings from Ulithian and Palauan on the Blust Yapese list, in addition to the form 
giriin 'green' from English or just possibly German, and this impact continues to be found to a similarly high degree throughout Yapese vocabulary. The richness of the Yapese vowel system is reminiscent in size and nature of the vowels found in that of Trukic languages such as Carolinian. Nonetheless, many of the features which make Yapese stand out from the other languages, such as the extensive glottalization in the form of numerous ejective consonants, come neither from Palauan nor Ulithian, nor, as far as I know, are they inherited from Proto-Admiralties (if that is Yapese's ancestor rather than its elder sister language): they are simply internal innovations. By contrast, the impact of other Western Micronesian languages (and this really means Chamorro) on Trukic languages is confined to a thin sliver of acculturational vocabulary which may predate strong Spanish contact (though Chamorro has had a stronger impact on Saipan Carolinian). This goes to show that in Western Micronesia some languages have been important donors, some have been major recipients, and some have been both.

\section{Appendix}

Statistics on the number and proportion of loan elements in some Micronesian languages

\section{Chamorro}

Approximately 38 per cent Spanish, 2.5 per cent Japanese and English, 0.5 per cent other (especially from Philippine languages), out of a total of c. 8,400 dictionary entries (Topping et al. 1973). Note. All these may be an underestimate, especially regarding the Spanish elements, which are found in all form classes in Chamorro. With the possible exception of a sole form from Pidgin English that also occurs in Tok Pisin (puspus 'to copulate'), all English loans are post- $1898 .{ }^{13}$

\section{Palauan}

Loans comprise 33 words from German, 63 from Spanish and 4 from Tagalog: over 660 from Japanese, plus 205 elements from English out of a total of c. 5,000 entries in McManus (Josephs 1977) and the lists on http://tekinged com/show_words.php. To the best of my knowledge, no loans originating in Palauan lexicon. Palauan has been a donor but hardly a recipient language in Western Micronesia. Most English loans are post-WWII.
Yapese

Out of a total of c. 2,900 entries in Jensen et al. (1977) which are not among the 147 personal or place names: 155+ items derive from a Nuclear Micronesian language, almost all from a Trukic language, probably Ulithian or Woleaian, 98 from Palauan, 15 from a lost language which was closely related to Palauan, 7 from an unidentified Oceanic language (possibly a Polynesian one), 102 from Japanese, 21 from German, 30 from Spanish, 157 from English, and there are a handful of early loans from Malay or Philippine languages which are often widely dispersed in other Western Micronesian languages. The same sources of elements are found in Nguluwan, which has sometimes made different loan choices from Yapese: Nguluwan lapis (< Spanish), Yapese pensel 'pencil' (<English). Many further loans from Palauan and Ulithian may actually be present and may be waiting to be spotted in the Yapese vocabulary. Most of the English loans in Yapese are post-WWII. Ross (1996) deals with much of this, and provides the insights on the Palauan-related language and the Oceanic language; other counts are the author's.

Woleaian

Out of some 4,000 entries in Sohn and Tawerilmang (1975), there are 300 words from Japanese, 100 from English, about 30 from Spanish, about 10 from German, a few others from other languages (peraas 'rice' from Malay, kaarebaw 'water buffalo, cattle' from Malay via Spanish or possibly Tagalog, and a few cultural loans from Yapese). Ulithian has a similar loan profile, maybe with fewer German loans but with more loans taken from Yapese (Walsh and Harui-Walsh 1979). Most of the English loans in Woleaian are post-WWII adoptions.

\section{Puluwatese}

Out of 6,300 entries and c. 4,000 stems in Elbert (1972), there are c. 18 stems from Spanish (some of them via Chamorro), c. 90 from Japanese, 7 from German, 5 from Pohnpeian, 2 from Mortlockese, also hundreds of loans from English.

Chuukese (Lagoon Trukese)

Out of c. 3,750 stem-level elements given in Goodenough and Sugita (1990), there are c. 310 from Japanese, c. 400 from English, 6 from Pidgin English, 5 from Latin, 4 from Chamorro, 1 each from Korean, Puluwatese and Samoan, 13 from German, 13 from Spanish, 6 from Mortlockese and 11 from Pohnpeian (statistics from Goodenough and Sugita 1990) 


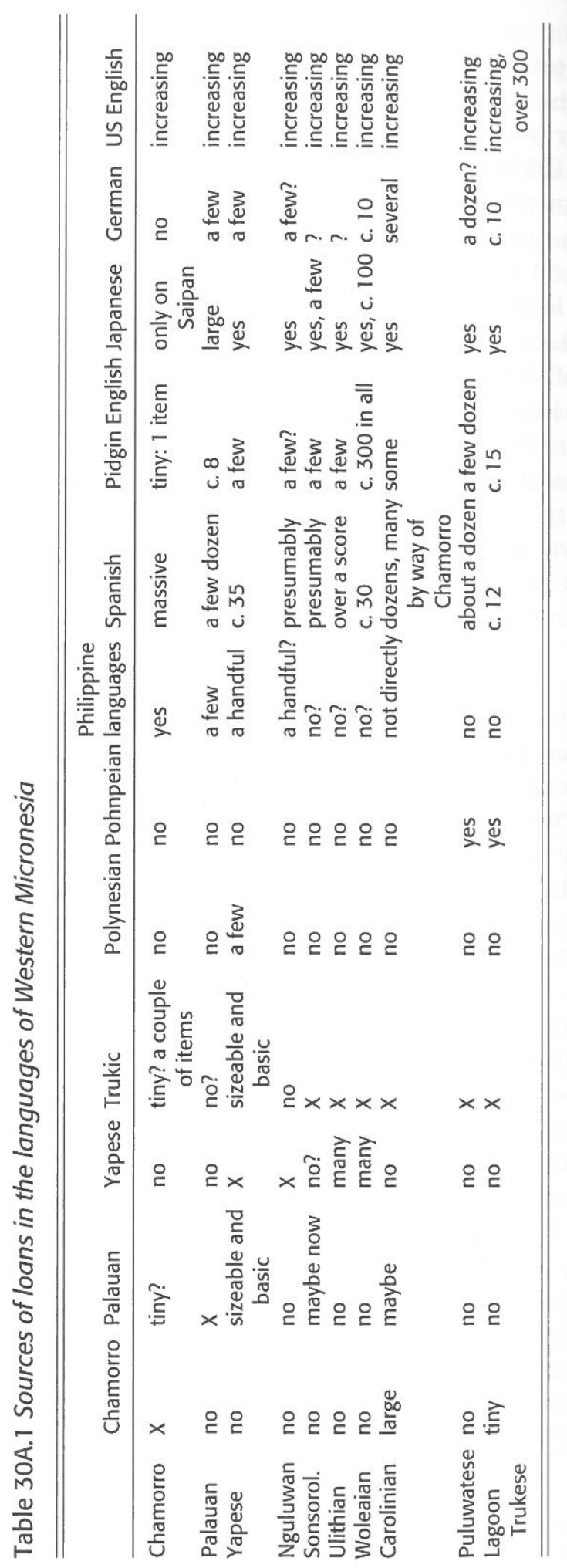

Sources of items employed in partial relexification (lexical replacement) in Western Micronesian languages

Chamorro Spanish, minimally Philippine, Oceanic and (on Saipan) Japanese.

Palauan Some Japanese, Spanish to a tiny extent.

Yapese Palauan, western Trukic, other Oceanic.

Nguluwan Palauan and especially Ulithian (at least four items on the

100- item Swadesh wordlist are Nouluwan loans from

Ulithian which are not also found in the sizable Ulithian

tranche of loans which have entered Yapese).

Sonsorolese ?none; maybe some nowadays from Palauan.

Ulithian ?none; some acculturational lexicon from Yapese.

Woleaian

?none; some acculturational lexicon from Yapese.

Puluwatese ?none; the sizable borrowed lexicon is all acculturational.

Lagoon Trukese ?(there are plenty of loans in the lexicon but they are not relexificational in nature). 


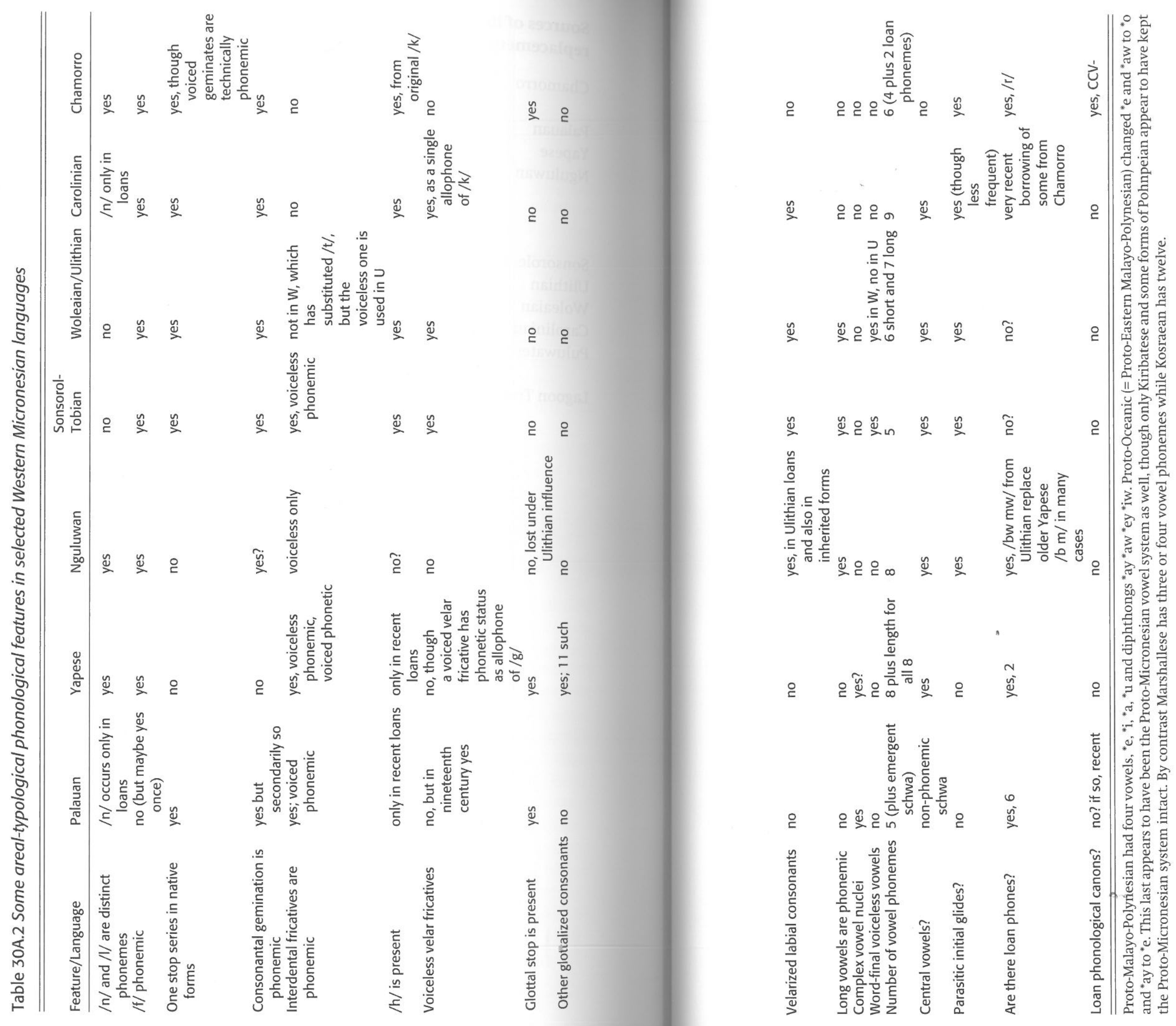




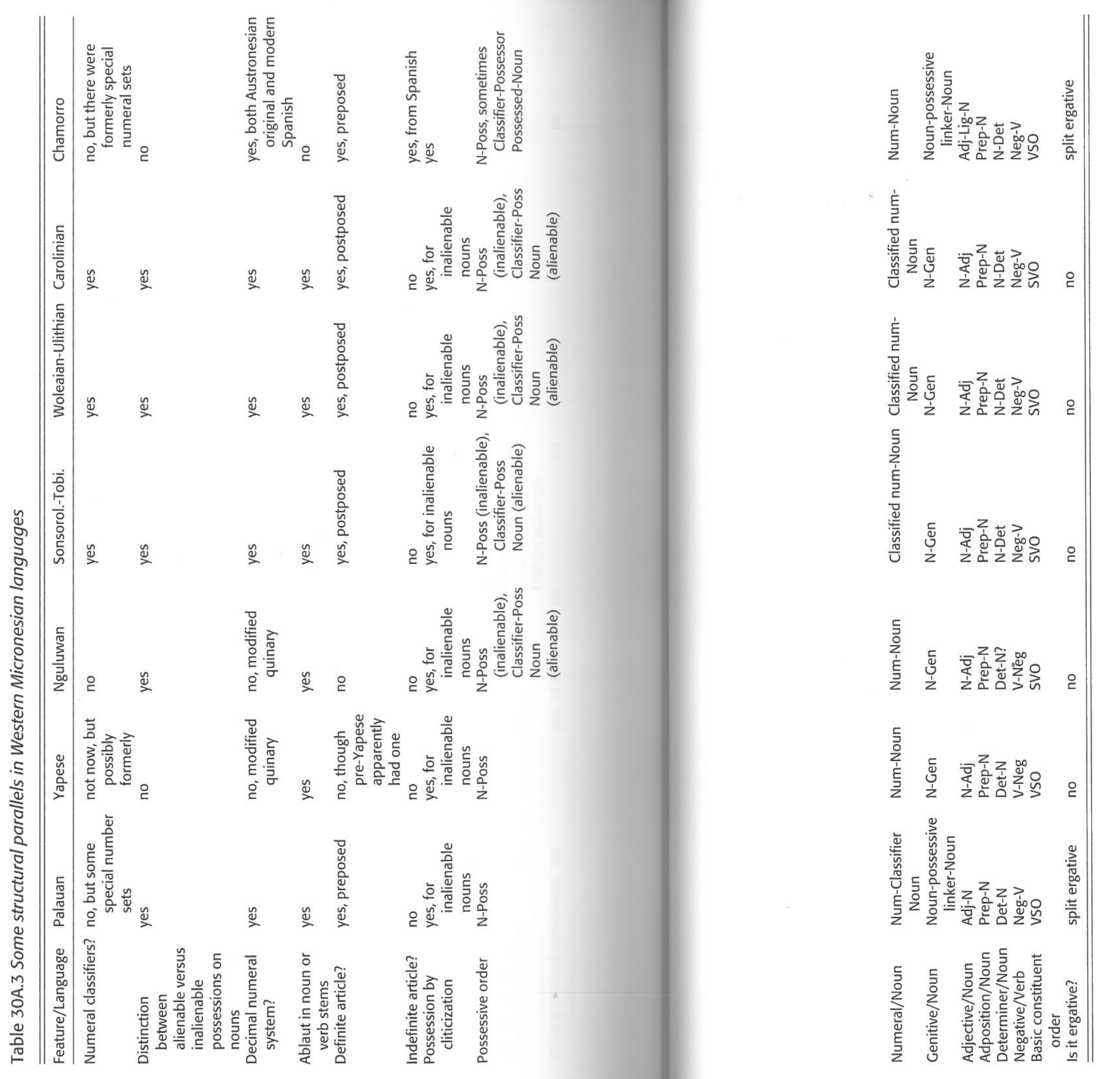


What is transferred in interlingual contact in Western Micronesia

- Acculturational lexicon of all kinds, including social borrowings such as greetings in Chamorro and some central and eastern turowings such as (this is true of all languages surveyed here)

Non-core lexicon (in some languages only: there is some borrowing from Japanese into Palauan and massive borrowing from Spanish into Chamorro, and extensive borrowing from Palauan and Tpanish into Yapese, with further Trukic loans found in Nguluwan and Trukic into

Core lexicon (strongly in Chamorro, also Yapese and Nguluwan, marginally in Palauan).

- Verbs which are incorporated into pre-existing morphological paradigms (there are many examples of these being borrowed in Chamorro, Nguluwan and Yapese).

- Loan phonemes (marginally and only recently in Yapese and Palauan, more strongly in Chamorro).

- New loan phonological canons.*

- Phonological features at a phonemic level (mid-vowels).*

- Adjectival comparative markers.

- Numerals.*

- Some personal and other pronouns.*

- Some conjunctions.*

- Some prepositions.*

- Some temporal, spatial and phasal adverbs.*

- Copula* (in part).

- Indefinite article.*

- Discourse markers (many in Chamorro and maybe some in Carolinian, also possibly a polite imperative marker in Nguluwan).

- Metatypy of constructions (copying of certain constructions from Ulithian to Nguluwan and from Spanish to Chamorro).

What remains undiffused from one language to another in these cases

- Bound morphs indicating either inflectional or derivational processes (the Spanish derivational affixes found in the Spanishderived lexicon in Chamorro rarely spread to pre-Spanish forms in the language).

- Free grammatical morphs (except in Chamorro, where several of these have been borrowed; these largely derive from Spanish).
Relative degrees of retention of Proto-Malayo-Polynesian items on the modified Swadesh list used in Blust (1981) and Jackson (1983: 227)

Malay $^{14}$

Chamorro

56 per cent

44 per cent

$\quad 37.9$ per cent

Chuukese $\quad 37.8$ per cent

Kiribatese $\quad 32$ per cent

Palauan 32 per cent

Pohnpeian 30.2 per cent

Marshallese 29.9 per cent

Kosraean 28.6 per cent

Yapese 18 per cent

\section{References}

Bender, Byron W., et al., 2003. Proto-Micronesian reconstructions, parts I, II. Oceanic Linguistics 42: 1-110, 271-358.

Blust, Robert, 1980. More on the origin of glottalic consonants. Lingua 52: 123-156.

Blust, Robert, 1981. Variation of retention rate among Austronesian languages. Paper presented at the Third International Conference on Austronesian Linguistics, Denpasar, Bali.

Blust, Robert, 2000. Chamorro historical phonology. Oceanic Linguistics 39: 83-123.

von Chamisso, Adelbert, 1864 [1836].'Reise um die Welt. Berlin: Weidmann. Costenoble, Hermann, 1940. Die Chamoro-Sprache. The Hague: Martinus Nijhoff.

Elbert, Samuel H., 1972. A Puluwat Dictionary. Pacific Linguistics, vol. C-24. Canberra: Australian National University.

Fritz, Georg, 1911. Die zentralkarolinische Sprache. Berlin: Reimer.

Goodenough, Ward H., 1992. Gradual and quantum changes in the history of Chuukese (Trukese) phonology. Oceanic Linguistics 31: 93-114.

Goodenough, Ward H. and Hiroshi Sugita (eds), 1990. Trukese-English Dictionary, Supplementary Volume: English-Trukese Finderlist. Philadelphia: American Philosophical Society.

Grant, Anthony P., 2002a. Fabric, pattern, shift and diffusion: What change in Oregon Penutian languages can tell historical linguists. In Laura Buszard-Welcher (ed.), Proceedings of the Meeting of the HokanPenutian Workshop, June 17-18, 2000, University of California at Berkeley, 
report 11: Survey of California and Other Indian Languages, pp. 33-56. Berkeley, CA: Department of Linguistics, University of California.

Grant, Anthony P., 2002b. Problems in placing Palauan within MalayoPolynesian. Unpublished manuscript, University of Manchester.

Grant, Anthony P., 2003. Review of Ruth King, The Lexical Basis of Grammatical Borrowing: A Prince Edward Island Case Study (Amsterdam: John Benjamins, 2000). Word 54 (3): 251-256.

Grant, Anthony P., 2014. The 'language of Tobi' as presented in Horace Holden's Narrative: Evidence for restructuring and lexical mixture in a Nuclear Micronesian-based pidgin. In Isabelle Buchstaller, Anders Holmberg and Mohammad Almoaily (eds), Pidgins and Creoles beyond Africa-Europe Encounters, pp. 41-56. Amsterdam: John Benjamins.

Hall, Robert A. Jr, 1945. English loan-words in Micronesian languages Language 21: 212-217.

Holden, Horace, 1836. Narrative of the Shipwreck, Captivity and Sufferings of Horace Holden and Benj. H. Nute. Boston: Russell, Shattuck and Co.

Izui, Hironasuke, 1965. The languages of Micronesia: Their origin and diversity. Lingua 15: 349-359.

Jackson, Frederick Henry, 1983. The Internal and External Relationships of the Trukic Languages of Micronesia. PhD dissertation, University of Hawai'i. Ann Arbor: University Microfilms International.

Jackson, Frederick H. and Jeffrey C. Marck, 1991. Carolinian-English Dictionary. Honolulu: University of Hawai'i Press.

Jensen, John Thayer, 1977. Yapese Reference Grammar. Honolulu: University of Hawai'i Press.

Jensen, John Thayer, Leo David Pugram and Raphael Defeg, 1977. Yapese-English Dictionary. Honolulu: University of Hawai'i Press.

Josephs, Lewis S., 1975. Palauan Reference Grammar. Honolulu: University of Hawai'i Press.

Josephs, Lewis S., 1977. Handbook of Palauan Grammar, two volumes. Koror: Bureau of Curriculum and Instruction, Ministry of Education.

Josephs, Lewis S., 1984. The impact of borrowing on Palauan. In Byron W. Bender (ed.), Studies in Micronesian Linguistics, pp. 81-123. Pacific Linguistics, vol. C-80. Canberra: Australian National University.

Lynch, John, Malcolm Ross and Terry Crowley, 2002. The Oceanic Languages. Curzon Language Family Series. Richmond, Surrey: Curzon Press.

McManus, Edwin, S.J., edited by Lewis S. Josephs, 1977. Palauan-English Dictionary. Honolulu: University of Hawai'i Press.

Reid, Lawrence A., 2002. Morphosyntactic evidence for the position of Chamorro in the Austronesian language family. In Robert S. Bauer (ed.), Collected Papers on Southeast Asian and Pacific Linguistics, pp. 63-94. Canberra: Australian National University.

Rodríguez-Ponga Salamanca, R., 1995. El elemento español en la lengua chamorra (Islas Marianas). Madrid: Servicio de Publicaciones de la Universidad Complutense
Ross, Malcolm, 1996. Is Yapese Oceanic? In Bernd Nothofer (ed.), Reconstruction, Classification, Description: Festschrift in Honor of Isidore Dyen, pp. 121-166. Hamburg: Abera.

Sakiyama, Osamu, 1982. The characteristics of Nguluwan from the viewpoint of language contact. In Machiko Aoyagi (ed.), Islanders and their Outside World: A Report of the Cultural Anthropological Research in the Caroline Islands of Micronesia in the Years 1980-1981, pp. 105-127. Tokyo: Committee for Micronesian Research, St Paul's (Rikkyo) University.

Salas Palomo, R. and Thomas Stolz, 2008. Pro or contra Hispanisms: Attitudes of native speakers of modern Chamoru. In Thomas Stolz, D. Bakker and R. Salas Palomo (eds), Hispanisation: The Impact of Spanish on the Lexicon and Grammar of the Indigenous Languages of Austronesia and the Americas, pp. 237-267. Berlin and New York: Mouton de Gruyter.

Sohn, Ho-Min 1975. Woleaian Reference Grammar. PALI Language Texts. Honolulu: University of Hawai'i Press.

Sohn, Ho-Min and Byron W. Bender, 1973. A Ulithian Grammar. Pacific Linguistics, vol. C-23. Canberra: Australian National University.

Sohn, Ho-Min and Anthony F. Tawerilmang, 1975. Woleaian-English Dictionary. Honolulu: University of Hawai'i Press.

Thomason, Sarah Grey, 2000. Linguistic areas and language history. In Dicky Gilbers, John Nerbonne and Jos Schaeken (eds), Proceedings of the Groningen Conference on Languages in Contact, pp. 311-327. Amsterdam: Rodopi.

Topping, Donald M. (with the assistance of Bernadita C. Dungca), 1973. Chamorro Reference Grammar. Honolulu: University of Hawai'i Press.

Topping, Donald M. and Pedro M. Ogo, 1980. Spoken Chamorro. Honolulu: University of Hawai'i Press.

Topping, Donald M., Pedro M. Ogo and Bernadita C. Dungca, 1975 Chamorro-English Dictionary. Honolulu: University of Hawai'i Press.

Walsh, John A. and Eulalia Harui-Walsh, 1979. Loan words in Ulithian. Anthropological Linguistics 21: 154-161.

Zobel, Erik, 2002. The position of Chamorro and Palauan in the Austronesian family tree: Evidence from verb morphosyntax. In Fay Wouk and Malcolm Ross (eds), The History and Typology of Western Austronesian Voice Systems, pp. 406-434. Pacific Linguistics, vol. 520 Canberra: Australian National University. 


\section{The Cambridge Handbook of Areal Linguistics}

Edited by

The Cambridge Handbook of Phonology, edited by Paul de Lacy

The Cambridge Handbook of Linguistic Code-switching, edited by Barbara E. Bullock and Almeida Jacqueline Toribio

The Cambridge Handbook of Child Language, Second Edition, edited by Edith L. Bavin and Letitia Naigles

The Cambridge Handbook of Endangered Languages, edited by Peter K. Austin and Julia Sallabank

The Cambridge Handbook of Sociolinguistics, edited by Rajend Mesthrie

The Cambridge Handbook of Pragmatics, edited by Keith Allan and Kasia M. Jaszczolt

The Cambridge Handbook of Language Policy, edited by Bernard Spolsky

The Cambridge Handbook of Second Language Acquisition, edited by Julia Herschensohn and Martha Young-Scholten

The Cambridge Handbook of Biolinguistics, edited by Cedric Boeckx and Kleanthes K. Grohmann

The Cambridge Handbook of Generative Syntax, edited by Marcel den Dikken

The Cambridge Handbook of Communication Disorders, edited by Louise Cummings The Cambridge Handbook of Stylistics, edited by Peter Stockwell and Sara Whiteley The Cambridge Hondbook of Linguistic Anthropology, edited by NJ. Enfield, Paul Kockelman and Jack Sidnell

The Cambridge Handbook of English Corpus Linguistics, edited by Douglas Biber and Randi Reppen

The Cambridge Handbook of Bilingual Processing, edited by John W. Schwieter

The Cambridge Handbook of Learner Corpus Research, edited by Sylviane Granger,

Gaëtanelle Gilquin and Fanny Meunier

The Cambridge Handbook of English Historical Linguistics, edited by Merja Kytö and Päivi Pahta

The Cambridge Handbook of Linguistic Multicompetence, edited by Li Wei and Vivian Cook

\section{Forthcoming}

The Cambridge Handbook of Formal Semantics, edited by Maria Aloni and Paul Dekker

The Cambridge Handbook of Linguistic Typology, edited by Alexandra Aikhenvald and R. M. W. Dixon 


\section{CAMBRIDGE}

University Printing House, Cambridge CB2 8BS, United Kingdom

Cambridge University Press is part of the University of Cambridge.

It furthers the University's mission by disseminating knowledge in the pursuit of education, learning, and research at the highest international levels of excellence.

www.cambridge.org

www.cambridge.org/9781107051614

(c) Cambridge University Press 2017

This publication is in copyright. Subject to statutory exception and to the provisions of relevant collective licensing agreements, peresion

First published 2017

Printed in the United Kingdom by TJ International Ltd., Padstow, Cornwal

A catalogue record for this publication is available from the British Library.

Library of Congress Cataloging-in-Publication Data

Hickey, Raymond, 1954- editor.

The Cambridge handbook of areal linguistics / edited by Raymond Hickey. Handbook of areal linguistics

Cambridge, United Kingdom : University Printing House, [2017]

Series: Cambridge handbooks in language and linguistics

LCCN 2016024593 | ISBN 9781107051614

LCSH: Areal linguistics - Handbooks, manuals, etc. | Linguistic geography -

Handbooks, manuals, etc.

-dc2

LC record available at https://lccn.loc.gov/2016024593

ISBN 978-1-107-05161-4 Hardback

Cambridge University Press has no responsibility for the persistence or accuracy of URLs for external or third-party Internet Web sites referred to in this publication and does not guarantee that any content on such Web sites is, or will remain,

accurate or appropriate.

\section{Contents}

List of Figure

page vii

List of Maps

List of Tables

List of Contributors

Preface

1 Areas, Areal Features and Areality Raymond Hickey

Part I Issues in Areal Linguistics

2 Why is it so Hard to Define a Linguistic Area? Lyle Campbell

3 Areas and Universals Balthasar Bickel

4 Reassessing Sprachbunds: A View from the Balkans

Victor A. Friedman and Brian D. Joseph

5 Areal Sound Patterns: From Perceptual Magnets to Stone Soup Juliette Blevins

6 Convergence and Divergence in the Phonology of the Languages of Europe Thomas Stolz and Nataliya Levkovych

Word Prominence and Areal Linguistics Harry van der Hulst, Rob Goedemans and Keren Rice

8 Semantic Patterns from an Areal Perspective

Maria Koptjevskaja-Tamm and Henrik Liljegren

Part II Case Studies for Areal Linguistics

9 The Germanic Languages and Areal Linguistics Johan van der Auwera and Daniël Van Olmen

Britain and Ireland Raymond Hickey

11 Varieties of English Bernd Kortmann and Verena Schroter

12 Slavic Languages Alan Timberlake

13 The Caucasus Sven Grawunder

14 Western Asia: East Anatolia as a Transition Zone Geoffrey Haig 396 